\title{
Effect of Human Growth Hormone on Muscle and Adipose Tissue Metabolism in the Forearm of Man*
}

\author{
David Rabinowitz, $†$ Gerald A. Klassen, $\ddagger$ and Kenneth L. Zierler \\ (From the Department of Medicine, The Johns Hopkins University and Hospital, \\ Baltimore, $M d$.)
}

Previous reports concerning the effects of human, bovine, and porcine growth hormone on carbohydrate and fat metabolism are disparate. Growth hormone has been variously stated to be without effect, to increase, to depress, and to have a biphasic action on glucose uptake of excised rat hemidiaphragm (1-5), on isolated perfused rat heart $(6,7)$, and on the blood glucose concentration of man and rat $(8,9)$. With respect to effects on fat metabolism, injection of growth hormone consistently provokes, within a matter of hours, a rise in plasma free fatty acids (FFA) $(10,11)$, but in those experiments where earlier effects have been looked for, an initial hypolipacidemia has been reported $(12,13)$. These observations have been difficult to reconcile with reports of poor or erratic lipolytic activity displayed by growth hormone preparations on excised rat adipose tissue (14).

Much of the conflicting literature may arise from use of impure pituitary extracts, inadequate recognition of species specificity for growth hormones, and use of pharmacologic doses of the

\footnotetext{
* Submitted for publication August 13, 1963 ; accepted September 11, 1964.

These studies were supported by U. S. Public Health Service research grants AM 00750 and AM 05524, graduate training grant 2A-5232 from the National Institute of Arthritis and Metabolic Diseases, and a grant-in-aid from the Muscular Dystrophy Associations of America, Inc.

Presented in part at the forty-fifth meeting of the Endocrine Society, Atlantic City, N. J., June 1963. A summary of the results of these experiments has been incorporated in a synthesizing review: Roles of insulin and growth hormone, based on studies of forearm metabolism in man. Medicine 1963, 42, 385.

$\dagger$ The work was done during the tenure of an Established Investigatorship of the American Heart Association.

$\ddagger$ The work was done during the tenure of an $R$. Samuel McLaughlin Travelling Fellowship, Toronto, Ontario, Canada.
}

hormone which $a$ ) may well produce effects dissimilar from those following a smaller dose, $b$ ) may result in inability to distinguish the true action of growth hormone from the systemic contraresponse it has stimulated $(6,9,11,15)$, or both.

Direct effects of a hormone may be studied by measurement of blood (or plasma) flow and change in arteriovenous differences of selected metabolites across the human forearm following constant close intra-arterial injection of the hormone in a dose large enough to affect local metabolism but too small to produce systemic effects. The purpose of this report is to describe the effects of human growth hormone $(\mathrm{HGH})$, administered in this fashion, on muscle and adipose tissue metabolism in situ. HGH significantly reduced basal glucose uptake of muscle and adipose tissue, promoted uptake of FFA by skeletal muscle and FFA output from adipose tissue, and effected net movement of potassium into forearm tissues.

These effects are reminiscent of the pattern of basal forearm metabolism in active acromegaly (16) and in normal subjects in whom endogenous growth hormone activity has been increased by fasting for 66 hours.

\section{Methods}

Seven young male subjects of normal body weight were studied. Their previous intake of carbohydrate was normal. No food was permitted after 8 p.m. of the night before the studies, which were performed during the morning hours from 8 a.m. to 1 p.m. Blood samples were collected between 10 a.m. and 1 p.m., that is, 14 to 17 hours after the last meal. The brachial artery (a), a draining forearm deep vein ( $d v$ ), and a draining forearm superficial vein (sv) were catheterized by techniques described previously (17). Blood flow to the forearm was measured by indicator-dilution techniques, based on continuous infusion of the dye T-1824 into the brachial artery. If blood flow is constant, as it was in our experiments, changes in arterio-deep venous 
(a-dv) concentration differences in glucose and $\mathrm{K}$ are, in the main, a measure of changes in uptake or output of glucose and $\mathrm{K}$ by forearm muscle. Arterio-deep venous concentration differences in FFA reflect the sum of two effects, the uptake of FFA by forearm muscle and the output of FFA by adipose tissue that mingles with muscle. Arterio-superficial venous concentration differences are employed to reflect forearm skin and subcutaneous adipose tissue metabolism. Errors and assumptions have been treated in detail elsewhere (18).

Glucose was measured by a glucose oxidase method, lactate by a lactic dehydrogenase technique. Potassium was measured by internal standard flame photometry and FFA by a modified Dole titration and extraction method. Details of these methods have been given (17).

Two sets of samples in five patients and three sets in two patients were taken under basal postabsorptive conditions. Basal values are the means of these estimations. On the morning of the experiment, an amount of human growth hormone ${ }^{1}$ (usually $3 \mathrm{mg}$ ) was weighed out, dissolved in $10 \mathrm{ml}$ of $155 \mathrm{mM} \mathrm{NaCl}$ solution, and then passed through a Seitz L-3 filter for sterilization. The filtrate was collected in a test tube, transferred to a volumetric flask to which a predetermined volume of $0.5 \%$ Evans Blue, T-1824 (usually $10 \mathrm{ml}$ ), had been added, and made up to a final volume of $25 \mathrm{ml}$ with 155 $\mathrm{mM} \mathrm{NaCl}$. The contents of the flask were transferred to a steel syringe for constant intra-arterial injection. All apparatus used for preparation of $\mathrm{HGH}$, other than the Seitz filter, was precoated with human albumin. $\mathrm{HGH}$ was infused at a rate of $0.2 \mu \mathrm{g}$ per $\mathrm{kg}$ of body wt per minute for 26 minutes in five subjects and for 35 minutes in two subjects. The dose was calculated from the amount weighed out from the original container; no

$1 \mathrm{HGH}$ (lot NIH-GH-HS44B) was obtained from Dr. A. E. Wilhelmi, through the Endocrinology Study Section, National Institutes of Health, Bethesda, Md., to whom we are indebted. allowance was made for losses during preparation and sterilization of $\mathrm{HGH}$.

Arterial and venous samples were taken 12, 18, and 26 minutes following the start of the $\mathrm{HGH}$ infusion and for about 30 minutes thereafter. Circulation to the wrist was excluded during and for 5 minutes before withdrawal of blood samples and for the entire period of HGH administration.

\section{Results}

\section{$H G H$ concentration in brachial arterial plasma}

The calculated concentration of $\mathrm{HGH}$ in brachial arterial plasma, which is the ratio of the known rate of injection of $\mathrm{HGH}$ to total forearm plasma flow, ranged from 300 to $600 \mathrm{~m} \mu \mathrm{g}$ per $\mathrm{ml}$ brachial arterial plasma. At the time these studies were first undertaken, we were under the impression that we were doubling the endogenous concentration of HGH (19). The subsequent work of Utiger, Parker, and Daughaday (20) and of Glick, Roth, Yalow, and Berson (21) has shown this concentration to be many times the average for $\mathrm{HGH}$ in the basal state, but less than ten times the concentration that man produces after prolonged fasting (21).

\section{Plasma flow}

Plasma flow remained acceptably constant in these experiments. The range of variation of mean plasma flow during the period of $\mathrm{HGH}$ infusion was between 2.7 and $3.0 \mathrm{ml}$ per minute per $100 \mathrm{ml}$ arm.

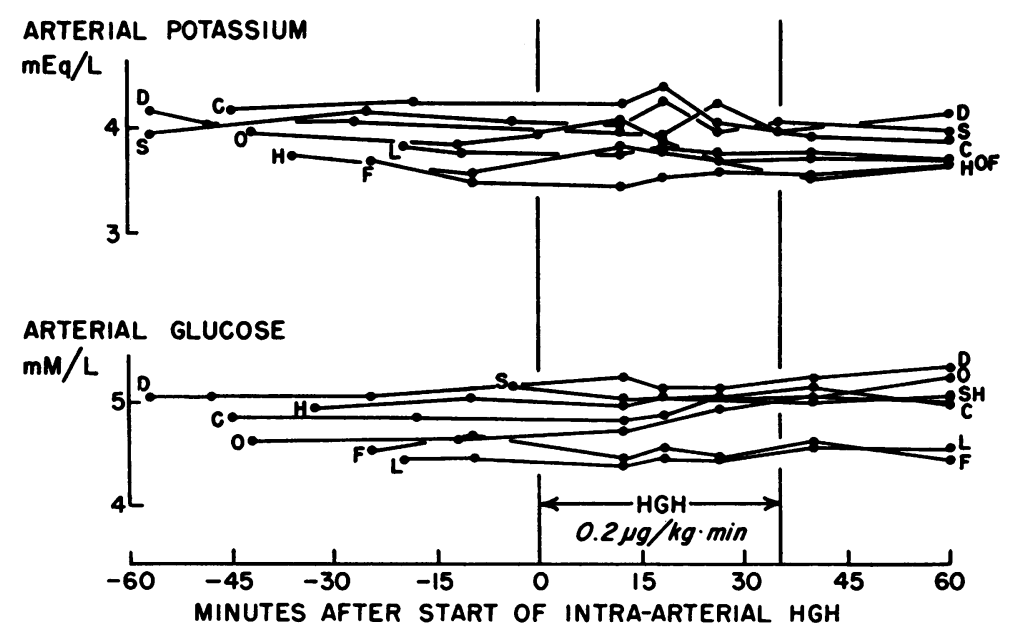

Fig. 1. Course OF ARTERIAL GLUCOSE AND POTASSIUM CONCENTRATIONS BEFORE, DURING, AND AFTER HUMAN GROWTH HORMONE (HGH) ADMINISTRATION. Each subject is identified by an initial. 
TABLE I

Course of arterial FFA concentration before, during, and after intra-arterial infusion of human growth hormone $(H G H)^{*}$

\begin{tabular}{|c|c|c|c|c|c|c|c|}
\hline \multirow[b]{2}{*}{ Subjects } & \multicolumn{2}{|c|}{ Minutes before HGH } & \multicolumn{5}{|c|}{ Minutes during and after HGH } \\
\hline & -60 to -20 & -20 to 0 & 12 & 18 & 26 & 38 & 60 \\
\hline & \multicolumn{2}{|c|}{$\mu$ moles $/ \mathrm{ml}$} & \multicolumn{5}{|c|}{ 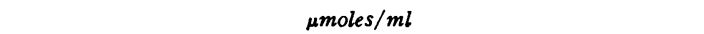 } \\
\hline $\mathrm{C}$ & 0.64 & 0.68 & 0.68 & 0.74 & 0.76 & 0.73 & 0.74 \\
\hline$\breve{H}$ & 0.78 & 0.69 & 0.67 & 0.75 & 0.71 & 0.82 & 0.81 \\
\hline $\mathrm{O}$ & 0.61 & 0.60 & 0.58 & & 0.67 & 0.64 & 0.68 \\
\hline $\mathbf{F}$ & 0.87 & 1.05 & 1.16 & 1.05 & 1.30 & 1.28 & 1.30 \\
\hline$\overline{\mathbf{L}}$ & & 0.97 & 1.12 & & 1.26 & 1.36 & 1.35 \\
\hline $\mathrm{S}$ & 0.74 & 0.80 & 0.68 & 0.68 & 0.69 & 0.75 & 0.79 \\
\hline $\mathrm{D}$ & 0.87 & 0.81 & 1.10 & 0.98 & 1.08 & 1.02 & 1.07 \\
\hline
\end{tabular}

* HGH was administered for 26 minutes in five subjects and for 35 minutes in two subjects (S and D). In this Table values obtained between 60 and 20 minutes $(-60$ to -20$)$ and again between 20 and 0 minutes $(-20$ to 0$)$ before starting the HGH infusion illustrate spontaneous fluctuations in arterial FFA concentration. In this Table and in Tables III, IV, and V, values shown at 38 minutes were obtained at 40 minutes in five subjects and at 35 minutes in two subjects (S and D).

Arterial concentration of metabolites (Figure 1 and Table I)

Mean changes in arterial glucose and potassium concentrations were in a direction expected from the observed local response but were small (less than $5 \%$ in each case). Because arterial concentration of FFA is labile under basal postabsorptive conditions, it is difficult to distinguish spontaneous from hormone-induced alterations in arterial FFA. Low concentrations tend to rise spontaneously with time; high values tend to fall (17). In light of these considerations, the course of arterial FFA in subjects $\mathrm{C}, \mathrm{H}, \mathrm{O}, \mathrm{S}$, and $\mathrm{L}$ may be considered not to have varied unusually (Table I). The remaining two subjects showed a rise in arterial FFA during the course of the experiment from values that initially were rather high. As we shall show, HGH induced profound local effects on FFA release from subcutaneous adipose tissue in these subjects, as reflected by the increase in sv-a FFA differences (see Figure 7). It is therefore possible that the arterial hyperlipacidemia in these two subjects represents a systemic effect of $\mathrm{HGH}$.

\section{Effects of HGH on tissues drained by the deep vein}

$\mathrm{O}_{2}, \mathrm{CO}_{2}$, and respiratory quotient $(\mathrm{RQ})$ (Table II). Gas exchange across the forearm was measured in six subjects. The increase noted in forearm $\mathrm{O}_{2}$ consumption in active acromegaly (16) was not reproduced by acute HGH administration to normal subjects. Mean forearm $R Q$ fell significantly, a change consequent upon a fall in a-dv $\mathrm{CO}_{2}$ differences (Table II).

Glucose (Table III, Figure 2). Basal a-dv glucose and glucose uptake $\left(\dot{Q}_{G}\right)$ by forearm tissues were by chance larger in this group of subjects than in our over-all experience (17). HGH decreased glucose a-dv differences in each of the seven subjects (Table III). Mean a-dv glucose fell from $0.27 \mu$ moles per $\mathrm{ml}$ basally to values of $0.18,0.16$, and 0.11 at 12,18 , and 26 minutes, respectively, after the start of infusion of $\mathrm{HGH}$. That is, HGH reduced uptake by about half.

Lactate (Figure 3). Lactate a-dv differences decreased (i.e., became less negative) after $\mathrm{HGH}$ administration in each of the six subjects on whom measurements were made. Mean a-dv lactate fell by about $50 \%$ after $\mathrm{HGH}$ administration (Figure 3). HGH thus provoked about the same percentage of decrease in glucose uptake as in lactate production, and consequently there was little change in the $L / G$ ratio, which is defined as the

TABLE II

Effect of $H G H$ on arterio-deep venous ( $a-d v)$ concentration differences of $\mathrm{O}_{2}$ and $\mathrm{CO}_{2}$, and on respiratory quotient $(R Q)$ of deep forearm tissues*

\begin{tabular}{lcccc}
\hline \hline & Before HGH & $\begin{array}{c}\text { HGH, 26 } \\
\text { minutes }\end{array}$ & $\begin{array}{c}\text { Paired } \\
\text { differences }\end{array}$ & $\mathrm{p}$ \\
\hline $\begin{array}{c}\text { a-dv CO2, } \\
\mu \text { moles } / m l\end{array}$ & $-2.29 \pm 0.29$ & $-1.46 \pm 0.26$ & $-0.83 \pm 0.31$ & $<0.05$ \\
$\begin{array}{c}\text { a-dv O2, } \\
\mu m o l e s / m l\end{array}$ & $3.00 \pm 0.39$ & $2.24 \pm 0.36$ & $-0.76 \pm 0.46$ & $\mathrm{NS}$ \\
$\mathrm{RQ}$ & $0.78 \pm 0.047$ & $0.66 \pm 0.036$ & $-0.12 \pm 0.038$ & $<0.05$ \\
\hline
\end{tabular}

* All values are means \pm standard error of means among six subjects. p is probability that the observed paired differences differed by
chance from 0 . 


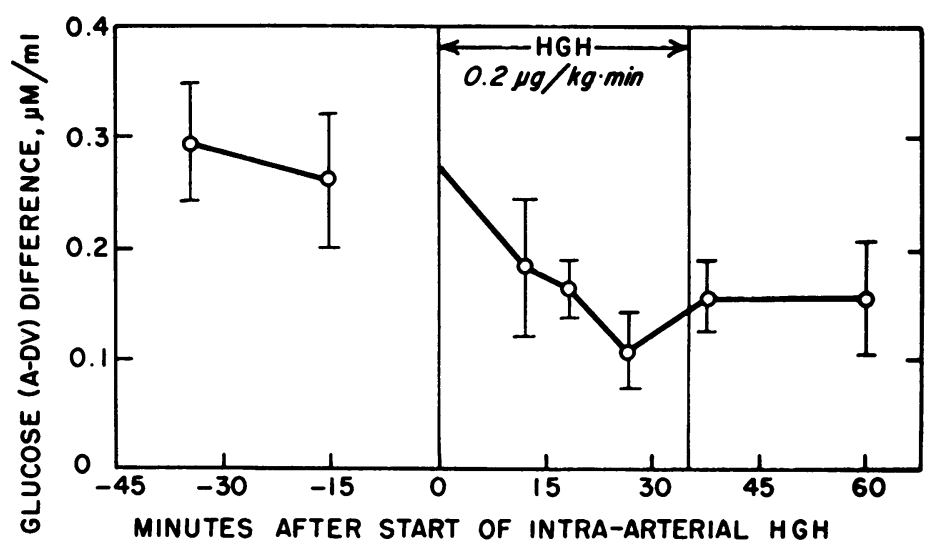

Fig. 2. Course of A-DV GLUCOSE DIFFERENCES BEFore, DURING, AND after HGH administration. Data are plotted as means \pm standard error of the mean. HGH was administered for 26 minutes in five subjects and for 35 minutes in two subjects. Points plotted at -35 minutes and -15 minutes in this Figure and in Figures 5 and 6 are, respectively, the means of all measurements made between -60 and -20 minutes and between -20 and 0 minutes before $\mathrm{HGH}$ infusion commenced. Points plotted at 38 minutes are the means of values obtained at 40 minutes in five subjects and at 35 minutes in two subjects.

fraction of glucose uptake that can be accounted for by lactate production. Since $\mathrm{O}_{2}$ consumption remained stable in the face of reduced glucose uptake by forearm, the fraction of observed $\mathrm{O}_{2}$ consumption accounted for by glucose oxidation, $(\mathrm{G}-\mathrm{L}) / \mathrm{O}_{2}$, decreased following the $\mathrm{HGH}$ infusion.

$F F A$ (Table IV, Figure 4). Arterio-deep venous FFA increased (that is, became positive or more positive) in each of the seven subjects following HGH. This effect was detectable with the first sample, 12 minutes after infusion of $\mathrm{HGH}$ be- gan, and plateaued at about $0.1 \mu$ mole per $\mathrm{ml}$ between 18 and 40 minutes.

Owing to anatomic considerations, the Fick principle is not entirely applicable to assessment of FFA metabolism in human forearm. Deep venous effluent drains not only muscle but also adipose tissue, which is intimately streaked among muscle fibers. Arterio-deep venous FFA differences therefore reflect both uptake of FFA by skeletal muscle and release of FFA by adipose tissue. The increase in a-dv FFA after HGH may be owing to reduced FFA release from forearm adi-

TABLE III

Effect of HGH on a-v glucose differences*

\begin{tabular}{|c|c|c|c|c|c|c|c|c|c|c|c|c|}
\hline \multirow{2}{*}{$\begin{array}{l}\text { Minutes } \\
\text { after } \\
\text { HGH: } \\
\text { Subjects }\end{array}$} & \multirow{2}{*}{$\begin{array}{c}\text { Basal } \\
\text { a-dv } \\
0\end{array}$} & \multicolumn{5}{|c|}{ Change in $a-d v$} & \multirow{2}{*}{$\begin{array}{c}\text { Basal } \\
\text { a-sv } \\
0\end{array}$} & \multicolumn{5}{|c|}{ Change in a-sv } \\
\hline & & 12 & 18 & 26 & 38 & 60 & & 12 & 18 & 26 & 38 & 60 \\
\hline & $\mu m o l e / m l$ & & & $\mu$ mole $/ m l$ & & & $\mu m o l e / m l$ & & & $\mu$ mole $/ \mathrm{ml}$ & & \\
\hline C & 0.20 & -0.14 & -0.06 & -0.20 & -0.05 & -0.06 & 0.39 & -0.32 & -0.44 & -0.02 & -0.14 & -0.27 \\
\hline $\mathbf{H}$ & 0.40 & -0.26 & -0.15 & -0.21 & -0.22 & -0.27 & 0.34 & -0.26 & -0.11 & -0.12 & -0.06 & -0.15 \\
\hline $\mathrm{O}$ & 0.16 & & +0.01 & -0.04 & -0.04 & 0 & 0.19 & +0.03 & -0.15 & -0.17 & -0.14 & +0.36 \\
\hline$F$ & 0.31 & -0.21 & -0.18 & -0.24 & -0.03 & -0.17 & 0.33 & -0.09 & -0.03 & -0.15 & -0.04 & -0.18 \\
\hline $\mathbf{L}$ & 0.11 & -0.01 & -0.03 & -0.16 & -0.04 & -0.08 & 0.26 & -0.14 & -0.20 & -0.07 & -0.04 & \\
\hline $\mathrm{S}$ & 0.21 & 0 & & & -0.16 & -0.18 & 0.22 & -0.13 & & & -0.26 & -0.25 \\
\hline $\mathrm{D}$ & 0.54 & -0.03 & -0.28 & -0.28 & -0.25 & -0.06 & 0.53 & -0.04 & -0.04 & -0.25 & -0.18 & \\
\hline Mean & 0.27 & -0.11 & -0.12 & -0.19 & -0.11 & -0.12 & 0.32 & -0.14 & -0.22 & -0.13 & -0.12 & -0.10 \\
\hline$\pm \mathrm{SEM}$ & 0.053 & 0.040 & 0.043 & 0.034 & 0.035 & 0.034 & 0.044 & 0.045 & 0.066 & 0.032 & 0.030 & 0.117 \\
\hline
\end{tabular}

* HGH administered for 26 minutes in five subjects and for 35 minutes in two subjects (S and D), beginning at time 0 . Basal a-v glucose differences are the means of all values taken before HGH infusion. Change in a-v concentration difference obtained by subtracting a-v difference at time $t$ from a-v difference at time 0 . Data were calculated to two decime
error" accounts for what appear to be minor inconsistencies in some places. 
TABLE IV

Effect of $H G H$ on $a-v$ free fatty acid differences*

\begin{tabular}{|c|c|c|c|c|c|c|c|c|c|c|c|c|}
\hline \multirow{2}{*}{$\begin{array}{c}\text { Minutes } \\
\text { after } \\
\text { HGH : } \\
\text { Subjects }\end{array}$} & \multirow{2}{*}{$\begin{array}{c}\text { Basal } \\
\text { a-dv } \\
0\end{array}$} & \multicolumn{5}{|c|}{ Change in a-dv } & \multirow{2}{*}{$\begin{array}{c}\text { Basal } \\
\text { a-sv } \\
0\end{array}$} & \multicolumn{5}{|c|}{ Change in a-sv } \\
\hline & & 12 & 18 & 26 & 38 & 60 & & 12 & 18 & 26 & 38 & 60 \\
\hline & $\mu m o l e / m l$ & \multicolumn{5}{|c|}{$\mu m o l e / m l$} & $\mu$ mole $/ \mathrm{ml}$ & \multicolumn{5}{|c|}{$\mu m o l e / m l$} \\
\hline C & -0.05 & +0.05 & +0.13 & +0.14 & +0.14 & +0.08 & -0.08 & -0.02 & -0.01 & -0.01 & -0.12 & -0.10 \\
\hline $\mathbf{H}$ & +0.03 & +0.08 & +0.10 & +0.11 & +0.08 & +0.07 & -0.16 & +0.06 & +0.01 & -0.04 & -0.14 & -0.11 \\
\hline $\mathrm{O}$ & +0.06 & +0.04 & -0.01 & +0.02 & & +0.05 & -0.16 & +0.06 & +0.05 & +0.03 & -0.04 & -0.13 \\
\hline $\mathbf{F}$ & +0.05 & +0.01 & +0.07 & +0.04 & +0.11 & -0.23 & -0.28 & -0.04 & -0.11 & & -0.19 & \\
\hline $\mathbf{L}$ & +0.07 & & +0.18 & +0.05 & +0.18 & +0.10 & -0.19 & -0.02 & -0.01 & +0.05 & -0.10 & -0.22 \\
\hline $\mathbf{S}$ & 0 & & +0.04 & -0.01 & +0.07 & & -0.17 & +0.05 & -0.04 & -0.09 & -0.25 & -0.35 \\
\hline D & -0.31 & +0.26 & & +0.32 & +0.41 & +0.36 & -0.15 & -0.10 & -0.10 & -0.15 & -0.56 & -0.94 \\
\hline Mean & -0.02 & +0.09 & +0.08 & +0.10 & +0.16 & +0.07 & -0.17 & -0.02 & -0.03 & -0.04 & -0.20 & -0.31 \\
\hline SEM & 0.051 & 0.044 & 0.028 & 0.043 & 0.051 & 0.076 & 0.023 & 0.020 & 0.022 & 0.030 & 0.065 & 0.131 \\
\hline
\end{tabular}

* Data compiled as in Table III.

pose tissue, to enhanced FFA uptake by skeletal muscle, or to both. The first solution is quite unlikely because, as we shall see, $\mathrm{HGH}$ made a-sv FFA differences more negative, i.e., increased FFA output from subcutaneous adipose tissue. $\mathrm{HGH}$ probably has a similar action on the adipose tissue that mingles with muscle, an effect that should decrease (i.e., make more negative) a-dv FFA. Since a-dv FFA differences actually became more positive with $\mathrm{HGH}$, the conclusion that $\mathrm{HGH}$ has increased FFA uptake by muscle seems inescapable.

There are some uncertainties in quantifying the increase in a-dv FFA. The contribution of FFA to $\mathrm{dv}$ from adipose tissue leads to an underesti- mate of FFA uptake. On the other hand, measurement of $\mathrm{a}-\mathrm{v}$ differences in the presence of a rising arterial concentration leads to an overestimate of true uptake of the metabolite. This clearly is the case for a-dv FFA in subjects $F$ and L. However, an increase in a-dv FFA to $+0.09 \mu$ mole per $\mathrm{ml}$ or greater was also observed in the other five subjects in whom arterial FFA was reasonably stable. Thus, while we have reservations about accepting $+0.12 \mu$ mole per $\mathrm{ml}$ as the true peak a-dv FFA after HGH, it appears reasonably certain that the $\mathrm{HGH}$-induced increase in FFA uptake by deep forearm tissues is neither dependent upon nor is a spurious product of a rise in arterial FFA.

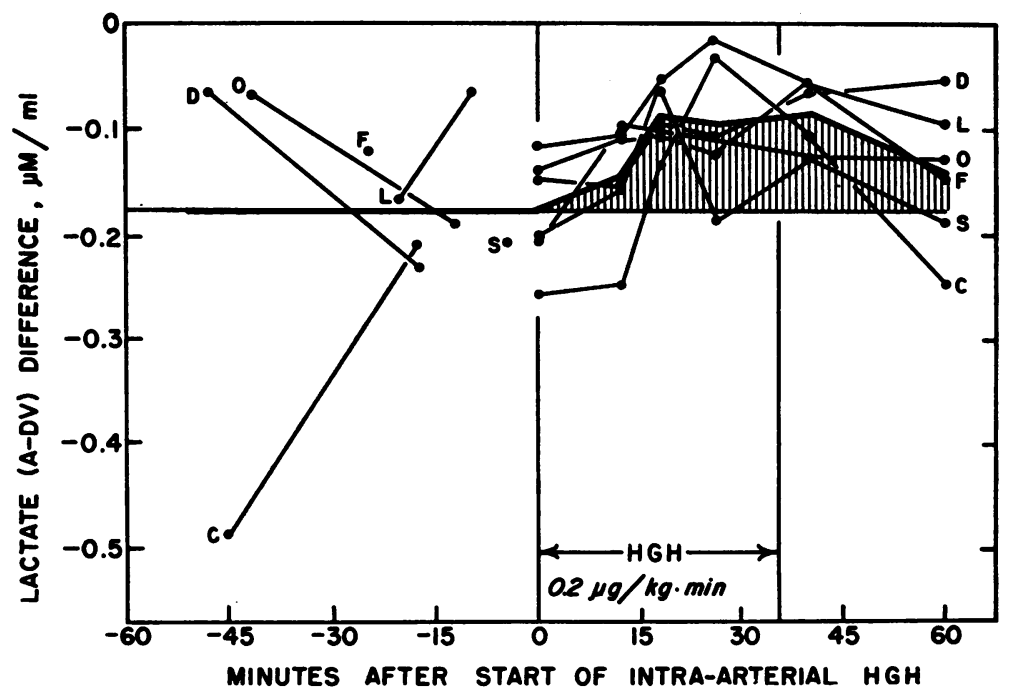

Fig. 3. COURSE OF A-DV LACTATE DIFFERENCES BEFORE, DURING, AND AFTER HGH IN SIX NORMAL SUBJECTS. Each of the six subjects is identified by an initial. Heavy lines are mean values. Shaded areas indicate differences from mean of a-dv lactate differences during the time preceding exhibition of $\mathrm{HGH}$. 


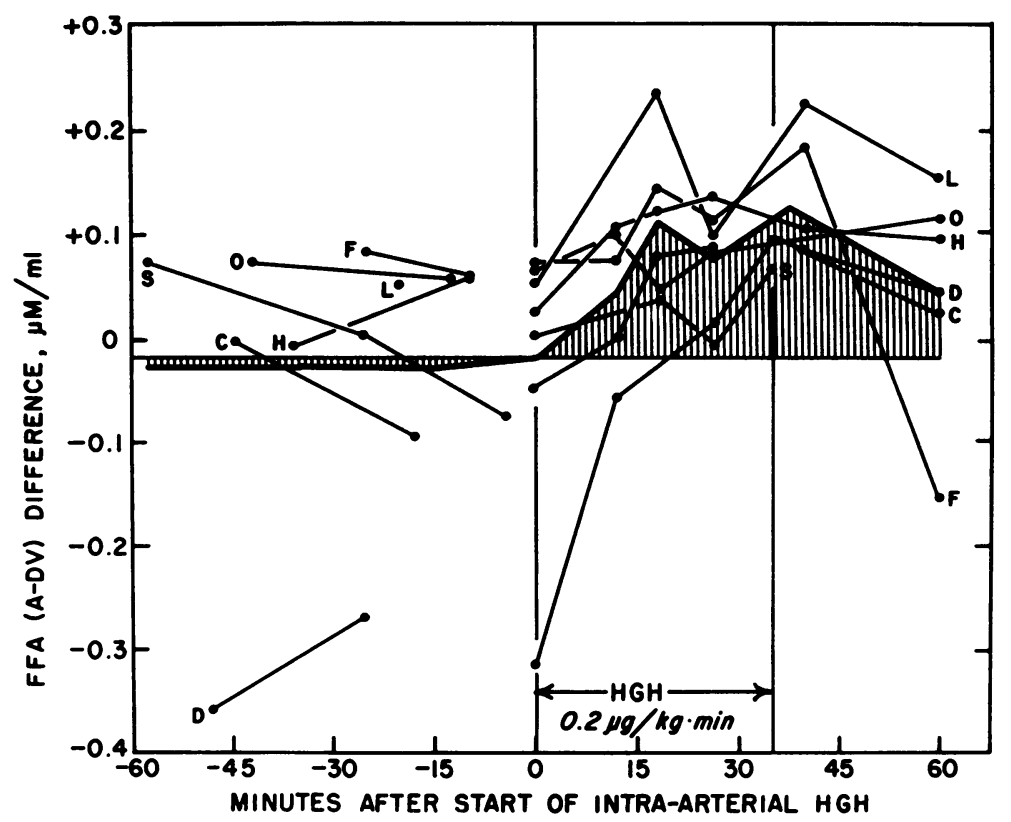

Fig. 4. CoURSE OF A-DV FFA DIFFERENCES BEFORE, DURING, AND AFTER HGH IN SEVEN NORMAL SUBJECTS. Each of the seven subjects is identified by an initial. Heavy lines are mean values; shaded areas indicate differences from mean of a-dv FFA differences during the time preceding exhibition of $\mathrm{HGH}$.

$F F A / \mathrm{O}_{2}$. If $\mathrm{dv}$ drained skeletal muscle only and did not include effluent perfusing adipose tissue, then a-dv FFA differences could be employed to calculate the fraction of $\mathrm{O}_{2}$ uptake accounted for by oxidation of FFA, defined by: $\mathrm{FFA} / \mathrm{O}_{2}=[(\mathrm{a}-\mathrm{dv}) \mathrm{FFA} \times 25 \times$ plasmacrit $] /$ (a-dv) $\mathrm{O}_{2}$.

This equation underestimates the role of FFA as substrate for forearm muscle because, as we pointed out in the previous paragraph, adipose tissue, mingling with muscle, does contribute FFA to $\mathrm{dv}$ blood.
In a previous set of experiments (22) we attempted to minimize distortion by adipose tissue of $\mathrm{dv}$ concentration of FFA by local infusion of insulin, which inhibits FFA release from forearm adipose tissue (22). This maneuver unmasked sufficient FFA uptake by forearm to account for between 50 and $60 \%$ of forearm $\mathrm{O}_{2}$ consumption in normal subjects. From this indirect approach, we suggested that basal FFA/O $\mathrm{O}_{2}$ was also between 0.5 and 0.6.

In the present series of experiments we administered only $\mathrm{HGH}$. Mean $\mathrm{FFA} / \mathrm{O}_{2}$ rose to values

TABLE V

Effect of HGH on a-v potassium differences*

\begin{tabular}{|c|c|c|c|c|c|c|c|c|c|c|c|c|}
\hline \multirow{2}{*}{$\begin{array}{l}\text { Minutes } \\
\text { after } \\
\text { HGH : } \\
\text { Subjects }\end{array}$} & \multirow{2}{*}{$\begin{array}{c}\text { Basal } \\
\text { a-dv } \\
0\end{array}$} & \multicolumn{5}{|c|}{ Change in a-dv } & \multirow{2}{*}{$\begin{array}{c}\text { Basal } \\
\text { a-sv } \\
0\end{array}$} & \multicolumn{5}{|c|}{ Change in a-sv } \\
\hline & & 12 & 18 & 26 & 38 & 60 & & 12 & 18 & 26 & 38 & 60 \\
\hline & $\mu$ mole $/ \mathrm{ml}$ & \multicolumn{5}{|c|}{$\mu m o l e / m l$} & umole $/ \mathrm{ml}$ & \multicolumn{5}{|c|}{ 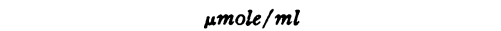 } \\
\hline C & -0.36 & +0.27 & +0.58 & +0.66 & +0.41 & +0.54 & -0.12 & +0.18 & +0.06 & +0.15 & +0.08 & +0.22 \\
\hline $\mathbf{H}$ & -0.16 & +0.23 & +0.23 & +0.18 & +0.25 & +0.21 & 0 & +0.07 & +0.04 & -0.01 & +0.11 & +0.04 \\
\hline O & -0.41 & +0.24 & +0.44 & +0.51 & & +0.55 & -0.02 & +0.15 & +0.15 & +0.11 & +0.27 & \\
\hline$F$ & +0.02 & -0.05 & +0.02 & +0.05 & +0.18 & +0.15 & -0.01 & -0.20 & +0.01 & +0.15 & -0.03 & +0.08 \\
\hline $\mathbf{L}$ & -0.26 & +0.32 & +0.35 & +0.29 & +0.41 & +0.37 & +0.02 & -0.02 & +0.10 & & +0.17 & \\
\hline $\mathbf{S}$ & -0.14 & +0.30 & +0.38 & & +0.24 & +0.23 & -0.11 & +0.29 & +0.32 & +0.07 & +0.17 & +0.14 \\
\hline $\mathrm{D}$ & -0.23 & +0.16 & +0.06 & +0.44 & +0.45 & +0.65 & -0.05 & -0.14 & -0.18 & +0.38 & & \\
\hline Mean & -0.22 & +0.21 & +0.29 & +0.36 & +0.32 & +0.39 & -0.04 & +0.05 & +0.07 & +0.14 & +0.13 & +0.12 \\
\hline SEM & 0.054 & 0.047 & 0.077 & 0.059 & 0.046 & 0.075 & 0.021 & 0.021 & 0.056 & 0.054 & 0.042 & 0.039 \\
\hline
\end{tabular}

* Data compiled as in Table III. 


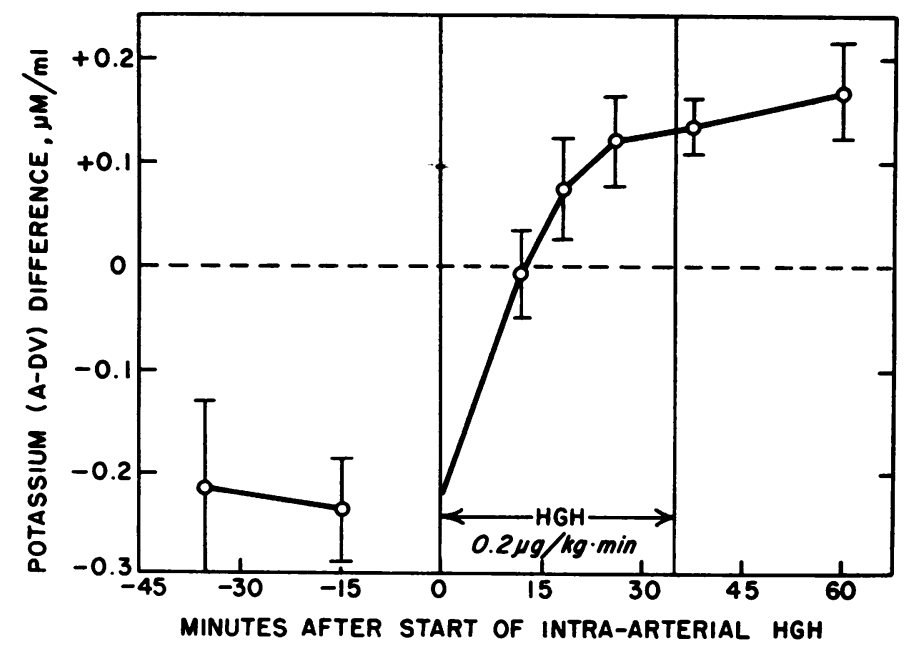

Fig. 5. EFFECT OF HGH oN A-DV POTASSIUM DIFFerences. Data are plotted as means \pm standard error of the mean.

of $0.77,0.53$, and 0.89 at 18,26 , and 40 minutes, respectively, after the start of $\mathrm{HGH}$.

These estimates are necessarily quite crude because they rest upon measurements of a-dv FFA differences and are subject to the same strictures just discussed. It is nevertheless evident that despite the natural barriers to efforts at quantifying forearm $\mathrm{FFA} / \mathrm{O}_{2}$, it is still possible to demonstrate that $\mathrm{HGH}$ elevates $\mathrm{FFA} / \mathrm{O}_{2}$ nearly to unity.

Potassium (Table V, Figure 5). Arterio-deep venous potassium became positive or more positive in each of the seven subjects after HGH.
This effect reached a plateau at 18 minutes, where it remained for the subsequent 42 -minute period of observation.

Effects of $H G H$ on tissues drained by the superficial vein (skin and adipose tissue)

Glucose and lactate (Table III, Figure 6). Changes in a-sv glucose and a-sv lactate paralleled changes in a-dv. Mean glucose a-sv differences fell from $0.32 \mu$ mole per $\mathrm{ml}$ to $0.12 \mu$ mole per $\mathrm{ml}$ (Figure 6), and mean lactate a-sv differences fell from $-0.26 \mu$ mole per $\mathrm{ml}$ to $-0.10 \mu$ mole per $\mathrm{ml}$, that is, $\mathrm{HGH}$ decreased glucose uptake and

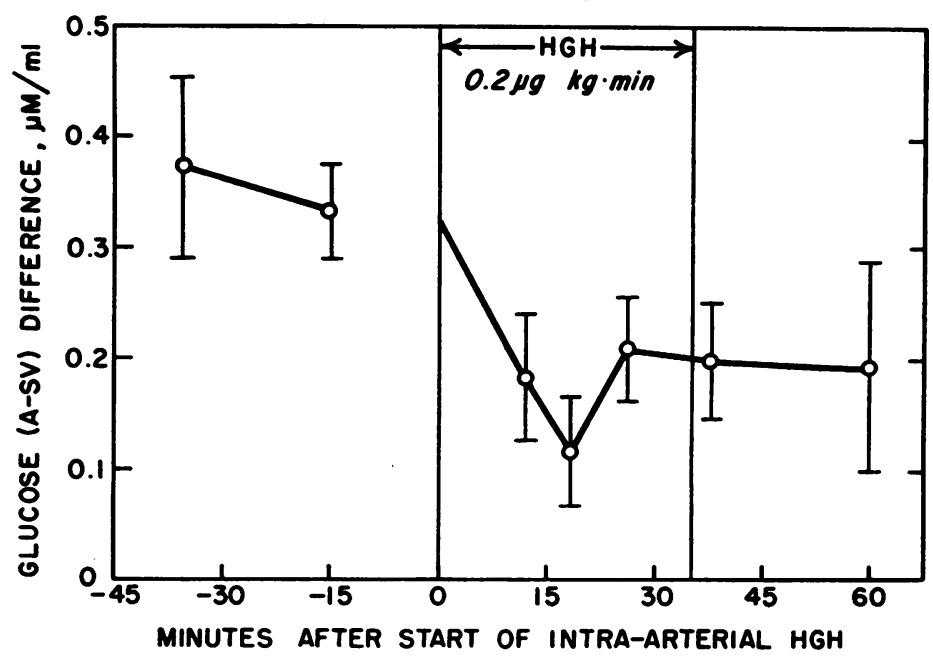

Fig. 6. COURSE OF A-Sv GLUCOSE DIFFERENCES BEFORE, DURING, AND AFTER HGH. Data are plotted as means \pm standard error of the mean. 


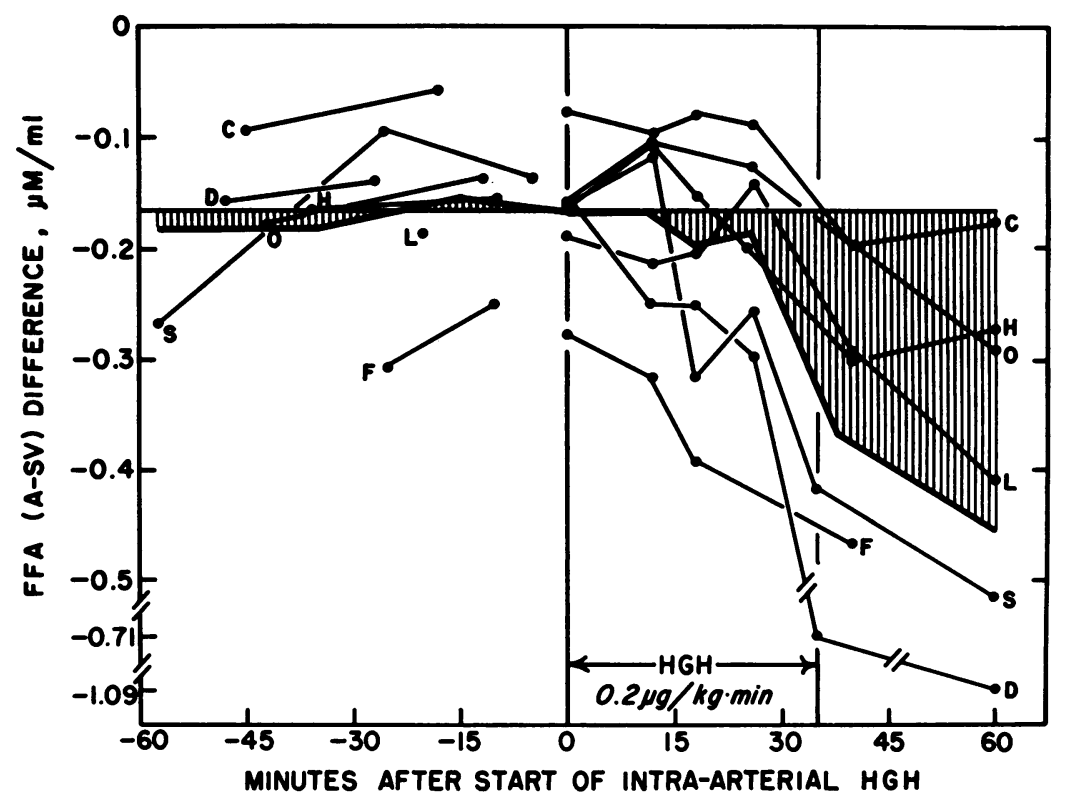

Fig. 7. Course of A-Sv FFA differences before, during, and After HGH IN SEVEN NORMAL SUBJECTS. Heavy lines are mean values. Shaded areas indicate differences from mean of a-sv FFA differences during the time preceding exhibition of $\mathrm{HGH}$.

lactate production across the superficial forearm bed to values between one-third and one-half basal values.

$F F A$ (Table IV, Figure 7). Arterio-superficial venous FFA, which reflects discharge of FFA from subcutaneous adipose tissue into venous plasma, was unchanged until 35 to 40 minutes after the start of the $\mathrm{HGH}$ infusion, at which time an increase of FFA output was observed, that is, a-sv FFA differences were more negative in each of the seven subjects. Enhanced FFA output was observed at 40 minutes in all subjects, irrespective of whether the period of $\mathrm{HGH}$ infusion was 26 minutes or 35 minutes. The delayed effect of $\mathrm{HGH}$ on FFA output contrasts with the prompt effects noted on other metabolic indexes in both deep and superficial forearm beds.

Potassium (Table V). HGH promoted K movement into skin and adipose tissue.

\section{Discussion}

These studies may help to resolve some conflicts about $\mathrm{HGH}$ effects on peripheral muscle and adipose tissue metabolism and may provide a clearer picture of the day-to-day role of $\mathrm{HGH}$ in adult body economy.

$\mathrm{HGH}$, in a local concentration of about 400 $\mathrm{m} \mu \mathrm{g}$ per $\mathrm{ml}$ of arterial plasma, reduced glucose uptake by forearm muscle and adipose tissue. No evidence was found for either an early insulinlike action peripherally (that is, an increase in glucose uptake by forearm) or for a biphasic action (i.e., an early increase followed by a subsequent decrease in glucose uptake), both of which have been reported by others $(2,5,8)$. In our study, the total dose of $\mathrm{HGH}$ administered over either 26 or 35 minutes never exceeded $500 \mu \mathrm{g}$, and it was without significant effect on arterial concentrations of glucose and potassium in all subjects. It may well be that HGH-induced hypoglycemia in man is $a$ ), as suggested by Zahnd, Steinke, and Renold (8), related to the size of the dose employed (usually $5 \mathrm{mg}$ or greater), $b$ ) an indirect effect, consequent upon change in the arterial concentration of one of the metabolites, or both.

In the basal state, about one-third the glucose taken up by deep and superficial forearm tissues can be accounted for as lactate (17). This fraction remained essentially unchanged during and following $\mathrm{HGH}$ administration. The fraction of forearm $\mathrm{O}_{2}$ consumption that could be accounted for by glucose oxidation fell, that is, following $\mathrm{HGH}$, substrate(s) other than glucose accounted 
for more than $80 \%$ of forearm $\mathrm{O}_{2}$ consumption, which itself was unchanged by HGH. The missing substrate appears to be FFA.

HGH has a twofold action on FFA metabolism: a) an immediate increase in FFA uptake by muscle and $b)$ a significant but delayed enhancement of FFA output from adipose tissue. These findings appear to provide a plausible explanation for the early fall and delayed rise in plasma FFA that follow systemic administration of $\mathrm{HGH}(12,13)$.

The notion that HGH enhances fat oxidation was proposed long ago (23). Greenbaum (24) reported an increase in fatty acid oxidation by rat liver slices taken from animals pretreated with growth hormone, but this effect was not seen earlier than about 6 hours after growth hormone administration. There are conflicting reports in the literature as to whether or not HGH influences FFA uptake and oxidation by muscle. Bodel, Rubenstein, McGarry, and Beck failed to show enhanced oxidation of palmitic acid-1-C ${ }^{14}$ by excised rat diaphragm either by addition of growth hormone in vitro or by pretreatment of the animals with growth hormone (25). On the other hand, de Bodo and colleagues $(26,27)$, on the basis of studies in which $\mathrm{C}^{14}$ palmitate was infused into normal dogs, reported that growth hormone administration increased the turnover rate of FFA, the amount of FFA oxidized to $\mathrm{CO}_{2}$, and the fraction of total respiratory $\mathrm{CO}_{2}$ derived from FFA oxidation.

The earliest measurable effect of $\mathrm{HGH}$ on FFA metabolism in human forearm was an increase in FFA uptake by muscle insofar as this is reflected by a-dv differences. The percentage of forearm $\mathrm{O}_{2}$ consumption accounted for by FFA oxidation $\left(\mathrm{FFA} / \mathrm{O}_{2}\right)$ increased to at least $89 \%$, considerably greater than current estimates of basal $\mathrm{FFA} / \mathrm{O}_{2}$.

We of course only measure net uptake of FFA by forearm tissues and are therefore not entitled to assume that FFA abstracted from plasma is being oxidized. Examination of forearm $R Q$ does, however, provide indirect information about the fuel combusted by forearm muscle. HGH produced a fall in $R Q$ from 0.75 , which suggests combustion of long chain fatty acids under basal conditions, to 0.66 , a change due entirely to a decrease in $\mathrm{CO}_{2}$ production by forearm. This change in $R Q$ may be explicable in the light of both a decreased glucose uptake and accelerated
FFA uptake by muscle. Following HGH, reduction in glucose translocation into muscle may result in decreased availability of oxalacetate. More FFA enters muscle than under basal conditions. It is possible then that incomplete dissimilation of long chain fatty acids, say to 4- or 2-carbon fragments, a process that results in $\mathrm{O}_{2}$ utilization without $\mathrm{CO}_{2}$ production, could account for the fall in forearm RQ. If muscle burns FFA exclusively following $\mathrm{HGH}$ (a plausible assumption in view of the minimal figure of $89 \%$ for $\mathrm{FFA} / \mathrm{O}_{2}$ ), then it can be calculated that incomplete combustion of 1 in 10 moles of FFA taken up would cause the observed fall in RQ. Our data on $R Q$ are, unfortunately, confined to observations under basal conditions and at the 26-minute sample following HGH. We do not know, therefore, whether there is a late rise in forearm $R Q$ that would attend final combustion of 2-carbon fragments.

With respect to effects of HGH on adipose tissue, our results confirm reports $(10,11)$ that HGH administration accelerates FFA release from adipose tissue, at least insofar as this is reflected by a-sv differences. We are unable to establish whether the 40-minute delay before a-sv FFA differences become more negative is real or whether any early effects have merely been masked by increased FFA uptake by nonadipose tissue drained by sv, for example, skin. Lipolytic properties of growth hormone in in vitro systems have been variously reported as absent, erratic, or achieved only with extremely high concentrations $(14,28-30)$. Raben has suggested that mobilization of FFA from adipose tissue is not mediated by HGH itself but is $a$ ) effected by a substance released remotely in response to HGH or $b$ ) secondary to some other local metabolic effect of $\mathrm{HGH}$ on adipose tissue (31). Enhanced FFA release by forearm adipose tissue after $\mathrm{HGH}$, even when arterial glucose and potassium (all subjects) and arterial FFA (five of seven subjects) were held constant, makes the first solution unlikely. The second hypothesis remains attractive and may have as its basis the HGH-induced decrease in glucose uptake by the intact adipose tissue.

$\mathrm{HGH}$ causes $\mathrm{K}$ to move in the net from arterial plasma into forearm tissues. The effect is as prompt as the effect of $\mathrm{HGH}$ on glucose, but 
whereas glucose movement is blunted, $\mathrm{K}$ movement into muscle is encouraged. This demonstrates that movement of $\mathrm{K}$ into muscle is not consequent upon glucose movement and can proceed at a time when glucose translocation has been virtually obliterated.

Effects on $\mathrm{K}$ are not unexpected in the light of significant $\mathrm{K}$ retention that follows $\mathrm{HGH}$ administration to total man $(32,33)$.

The role of $H G H$ in body economy. The growth hormone content of the pituitary does not vary with age (34), and absolute plasma $\mathrm{HGH}$ concentrations are probably not different in child and adult (19). HGH output, then, continues after linear growth has ceased. The notion that $\mathrm{HGH}$ output is enhanced during early starvation, first suggested by Young (35), Russell and Wilhelmi (36), and Golden, Bondy, Chambers, and Geiger (37), has been substantiated recently by Berson and collaborators (21). Metabolism of forearm in normal subjects fasted for 66 hours resembles the pattern produced by intra-arterial injection of $\mathrm{HGH}$ to subjects in the basal state (38).

The present studies highlight the importance of $\mathrm{HGH}$ to body economy during food-free intervals. Availability of glucose in man is always precarious, and liver glycogen stores are reduced greatly within 15 hours of food deprivation. HGH retards translocation of glucose into skeletal muscle and adipose tissue, thereby preserving blood glucose for use by nervous tissues. Although total mass of glucose in the $70-\mathrm{kg}$ man is only $350 \mathrm{~g}$, there are vast endogenous adipose tissue stores, comprising at least $14 \%$ of body weight or about $10 \mathrm{~kg}$. HGH enhances mobilization of FFA from adipose tissue and encourages oxidation of FFA by muscle. It may also act to retard $\mathrm{K}$ leakage from muscle.

These actions of $\mathrm{HGH}$ obtain during periods of famine, that is, in the remote postabsorptive period, when plasma insulin concentration is either very low or 0 (39). This may be very different from the role of $\mathrm{HGH}$ during periods of feast when endogenous plasma insulin concentration is at its maximum.

\section{Summary}

Forearm tissues are sensitive to local injection of human growth hormone ( $\mathrm{HGH}$ ) in a concen- tration of several hundred millimicrograms per milliliter brachial arterial plasma. $\mathrm{HGH}$ promotes entry of $\mathrm{K}$ into forearm muscle and adipose tissue and reduces glucose uptake and lactate production by deep and superficial forearm tissues. $\mathrm{HGH}$ enhances FFA uptake by muscle and increases release of FFA from adipose tissue, the former a prompt, the latter a delayed, response. As a result of $\mathrm{HGH}$ administration at least $89 \%$ of $\mathrm{O}_{2}$ uptake by forearm muscles can be attributed to oxidation of FFA.

\section{Acknowledgments}

We are indebted to those who volunteered for these experiments and to Misses Louise Margolet, Ellen Rogus, and Mary Retzel and Mmes. Mary Ann Isaacs and Marcia Lyons for technical assistance.

\section{References}

1. Park, C. R., and M. E. Krahl. Effect of pituitary extracts upon glucose uptake by diaphragms from normal, hypophysectomized, and hypophysectomized-adrenalectomized rats. J. biol. Chem. 1949, 181, 247.

2. Park, C. R., D. H. Brown, M. Cornblath, W. H. Daughaday, and M. E. Krahl. The effect of growth hormone on glucose uptake by the isolated rat diaphragm. J. biol. Chem. 1952, 197, 151.

3. Ottaway, J. H. The insulin-like action of growth hormone. Brit. med. J. 1953, 2, 357.

4. Randle, P. J. Enhancement of insulin action by pituitary growth hormone. Nature (Lond.) 1954, 174, 1053.

5. Riddick, F. A., Jr., D. M. Reisler, and D. M. Kipnis. The sugar transport system in striated muscle. Effect of growth hormone, hydrocortisone and alloxan diabetes. Diabetes 1962, 11, 171.

6. Bronk, M. S., and R. B. Fisher. The interaction of growth hormone and insulin in the perfused rat heart. J. Physiol. (Lond.) 1957, 136, 435.

7. Morgan, H. E., D. M. Regen, M. J. Henderson, T. K. Sawyer, and C. R. Park. Regulation of glucose uptake in muscle. VI. Effects of hypophysectomy, adrenalectomy, growth hormone, hydrocortisone, and insulin on glucose transport and phosphorylation in the perfused rat heart. J. biol. Chem. 1961, 236, 2162.

8. Zahnd, G. R., J. Steinke, and A. E. Renold. Early metabolic effects of human growth hormone. Proc. Soc. exp. Biol. (N. Y.) 1960, 105, 455.

9. Milman, A. E., and J. A. Russell. Some effects of purified pituitary growth hormone on carbohydrate metabolism in the rat. Endocrinology 1950, 47, 114. 
10. Raben, M. S., and C. H. Hollenberg. Effect of growth hormone on plasma fatty acids. J. clin. Invest. 1959, 38, 484.

11. Knobil, E., and R. O. Greep. The physiology of growth hormone with particular reference to its action in the rhesus monkey and the "species specificity" problem. Recent Progr. Hormone Res. 1959, 15, 1.

12. Pearson, O. H., J. M. Dominguez, E. Greenberg, A. Pazianos, and B. S. Ray. Diabetogenic and hypoglycemic effects of human growth hormone. Trans. Ass. Amer. Phycns 1960, 73, 217.

13. Swislocki, N. I., and C. M. Szego. Early metabolic effects of growth hormone in hypophysectomized and Houssay rats. Physiologist 1962, 5, 220.

14. White, J. E., and F. L. Engel. Lipolytic action of corticotropin on rat adipose tissue in vitro. $\mathrm{J}$. clin. Invest. 1958, 37, 1556.

15. Altszuler, N., R. Steele, J. S. Wall, A. Dunn, and R. C. de Bodo. Effect of growth hormone on carbohydrate metabolism in normal and hypophysectomized dogs; studies with $\mathrm{C}^{\mathbf{1 4}}$ glucose. Amer. J. Physiol. 1959, 196, 121.

16. Rabinowitz, D., and K. L. Zierler. Differentiation of active from inactive acromegaly by studies of forearm metabolism and response to intra-arterial insulin. Bull. Johns Hopk. Hosp. 1963, 113, 211.

17. Baltzan, M. A., R. Andres, G. Cader, and K. L. Zierler. Heterogeneity of forearm metabolism with special reference to free fatty acids. J. clin. Invest. 1962, 41, 116.

18. Andres, R., G. Cader, and K. L. Zierler. The quantitatively minor role of carbohydrate in oxidative metabolism by skeletal muscle in intact man in the basal state. Measurements of oxygen and glucose uptake and carbon dioxide and lactate production in the forearm. J. clin. Invest. 1956, 35, 671.

19. Read, C. H., and G. T. Bryan. The immunological assay of human growth hormone. Recent Progr. Hormone Res. 1960, 16, 187.

20. Utiger, R. D., M. L. Parker, and W. H. Daughaday. Studies on human growth hormone. I. A radioimmunoassay for human growth hormone. J. clin. Invest. 1962, 41, 254.

21. Glick, S. M., J. Roth, R. S. Yalow, and S. A. Berson. Hypoglycemia: potent stimulus to growth hormone secretion (abstract). J. clin. Invest. 1963, 42, 935.

22. Rabinowitz, D., and K. L. Zierler. Role of free fatty acids in forearm metabolism in man, quantitated by use of insulin. J. clin. Invest. 1962, 41, 2191.

23. Young, F. G. "Growth" and the diabetogenic action of anterior pituitary preparations. Brit. med. J. 1941, 2, 897.
24. Greenbaum, A. L. Growth hormone and fat metabolism in The Hypophyseal Growth Hormone, Nature and Actions, R. W. Smith, Jr., O. H. Gaebler, and C. N. H. Long, Eds. New York, McGrawHill, 1955, p. 330.

25. Bodel, P. T., D. Rubenstein, E. E. McGarry, and J. C. Beck. Utilization of free fatty acids by diaphragm in vitro. Amer. J. Physiol. 1962, 203, 311.

26. Winkler, B., R. Steele, N. Altszuler, A. Dunn, and R. C. de Bodo. Effects of growth hormone on FFA metabolism. Fed. Proc. 1962, 21, 198.

27. Winkler, B., R. Steele, N. Altszuler, and R. C. de Bodo. Effect of growth hormone on free fatty acid metabolism. Amer. J. Physiol. 1964, 206, 174.

28. Perry, W. F., and H. F. Bowen. Factors affecting the in vitro production of non-esterified fatty acid from adipose tissue. Canad. J. Biochem. 1962, 40, 749.

29. Leboeuf, B., and G. F. Cahill, Jr. Studies on rat adipose tissue in vitro. VIII. Effect of preparations of pituitary adrenocorticotropic and growth hormones on glucose metabolism. J. biol. Chem. 1961, 236, 41.

30. Krahl, M. E. Effect of pituitary hormones on metabolism of isolated tissues in The Hypophyseal Growth Hormone, Nature and Actions, R. W. Smith, Jr., O. H. Gaebler, and C. N. H. Long, Eds. New York, McGraw-Hill, 1955, p. 369.

31. Raben, M. S. Growth hormone. Recent Progr. Hormone Res. 1959, 15, 71.

32. Henneman, P. H., A. P. Forbes, M. Moldawer, E. F. Dempsey, and E. L. Carroll. Effects of human growth hormone in man. J. clin. Invest. 1960, 39, 1223.

33. Committee of Medical Research Council. The effectiveness in man of human growth hormone. Lancet 1959, 1, 7.

34. Gershberg, H. Growth hormone content and metabolic actions of human pituitary glands. Endocrinology 1957, 61, 160.

35. Young, F. G. Growth and diabetes in normal animals treated with pituitary (anterior lobe) diabetogenic extract. Biochem. J. 1945, 39, 515.

36. Russell, J. A., and A. E. Wilhelmi. The glycostatic action of purified growth hormone. Endocrinology 1950, 47, 26.

37. Golden, A., P. K. Bondy, R. W. Chambers, and C. L. Geiger. Adenohypophyseal changes in patients dying of neoplastic disease. Yale J. Biol. Med. 1961, 33, 299.

38. Rabinowitz, D., and K. L. Zierler. Unpublished observations.

39. Yalow, R. S., and S. A. Berson. Immunoassay of endogenous plasma insulin in man. J. clin. Invest. 1960, 39, 1157. 